\title{
Evaluation of a Toposequence of Soils Derived from Basalt by Fourier Transform Infrared Spectroscopy
}

\author{
Wilson Sacchi Peternella1*, Antônio Carlos Saraiva da Costa ${ }^{2}$ \\ ${ }^{1}$ Department of Chemistry, Federal University of Rondônia, Porto Velho Campus, Porto Velho, Brazil \\ ${ }^{2}$ Department of Agronomy, State University of Maringá, Maringá Campus, Maringá, Brazil \\ Email: *wpeternella@yahoo.com, antoniocscosta@gmail.com
}

How to cite this paper: Peternella, W.S. and da Costa, A.C.S. (2021) Evaluation of a Toposequence of Soils Derived from Basalt by Fourier Transform Infrared Spectroscopy. Open Access Library Journal, 8: e7867. https://doi.org/10.4236/oalib.1107867

Received: August 19, 2021

Accepted: September 6, 2021

Published: September 9, 2021

Copyright $\odot 2021$ by author(s) and Open Access Library Inc.

This work is licensed under the Creative Commons Attribution International License (CC BY 4.0).

http://creativecommons.org/licenses/by/4.0/ (c) (i) Open Access

\begin{abstract}
The interaction of organic matter (OM) and clay minerals has been studied as one of the main OM stabilization mechanisms present in different soil classes. The composition of OM present in the soil in terms of humic and fulvic acids and other organic compounds, together with the surface functional groups of different minerals of the clay fraction, such as iron and aluminum oxide and hydroxides type minerals, affect the intensity of the substrate/MO ratio, thus being able to change even the size of the crystals present in the clay mineral fraction. However, this effect is little evaluated due to the limitations in phase separation between OM and the mineralogical fraction of each soil. Therefore, the dissolution of iron oxides was conducted from the clay fraction with sodium dithionite-citrate-bicarbonate (DCB) for better evaluation of the silicate minerals in the soil. The nature of the functional groups of minerals from the clay fraction was evaluated by FTIR spectroscopy and compared with international standard kaolinite and montmorillonite; also evaluated using the technique of area ratio of the main absorption bands of soils derived from basalt and belonging to the toposequence. The results showed that FTIR spectroscopy analysis is a promising tool in the identification of clay minerals such as gibbsite, kaolinite and smectites, observing the due processes of separation of the fractions of interest.
\end{abstract}

\section{Subject Areas}

Soil Science

\section{Keywords}

Soil Toposequence, Organic Matter, Clay Minerals and FTIR 


\section{Introduction}

Soil is the most important compartment of the Earth's geosphere (Manahan, 2001) [1]. It is considered a natural and heterogeneous open system that exchanges energy and matter with the surroundings of the atmosphere, biosphere and hydrosphere. Its characteristics vary with time and space, due to its constant chemical, physical and biological changes, which also determine its fertility (Sposito, 1985) [2].

Tropical soils in humid climates have a high degree of weathering, for example, Oxisols, which are the types of soils that best represent pedogenetic trends, being defined as those that have a B-latosolic mineral subsurface horizon, which shows their advanced state of weathering (Camargo et al., 1988) [3].

Like most Brazilian soils, most soils in the State of Paraná, its clay fraction contains a small group of minerals such as kaolinite, gibbsite, oxides and hydroxides of $\mathrm{Fe}, \mathrm{Al}$ and $\mathrm{Mn}$, in addition to expansive minerals of type 2:1, such as vermiculite, illite and montmorillonite, which can influence the electrochemical attributes and, consequently, the phenomena of ionic adsorption and desorption from the soil solution. This composition is due to the advanced degree of weathering that these soils have as a characteristic.

In the soil, the solid phase is made up of a set of minerals and organic matter. Solid phase minerals are classified according to their particle diameter in sand (2 $\mathrm{mm}-50 \mu \mathrm{m})$, silt $(50-2 \mu \mathrm{m})$ and clay $(<2 \mu \mathrm{m})$. The minerals present in the clay fraction are essentially hydrated silicates and iron and aluminum oxides (Santos, 1989) [4].

In the structure of phyllosilicates a unit cell is composed of 20 oxygen atoms and 4 hydroxyls with eight tetrahedral and six octahedral sites, as described by (Santos, 1975) [5]. When all these sites are occupied by cations, the phyllosilicate is called a trioctahedron. When only two thirds are occupied by cations, it is a phyllosilicate dioctahedron.

Table 1 shows the classification of clays into groups and subgroups, according

Table 1. Classification of 2:1 type phyllosilicates as a function of the potential of permanent electrical charges.

\begin{tabular}{cccc}
\hline Charge & Group & Sub-group & name \\
\hline 0 & Pyrophyllite & Dioctahedron & Prioctahedron \\
Talc & Dioctahedron & Talc \\
& & Dioctahedron & Montmorillonite \\
& & Dioctahedron & Nontronite \\
$0.25-0.6$ & Smectite & Trioctahedron & Beidelite \\
& & Trioctahedron & Hectorite \\
& & Trioctahedron & Sauconite \\
& & Dioctahedron & Saponite \\
& & Trioctahedron & Vermiculite \\
$0.6-0.9$ & Vermiculite & Dioctahedron & Vermiculite \\
& & Trioctahedron & Muscovite \\
& Mica & & Biotite
\end{tabular}

Source: Santos (1975) [5]. 
to their permanent charge, where it should be noted that the permanent charges of these minerals that have these characteristics are not dependent on the $\mathrm{pH}$ of the medium. Permanent charges are the product of isomorphic ionic substitutions in mineral structures and always manifest at any $\mathrm{pH}$ of different soils. Therefore, this charge is specific to the mineral and can also be called structural charge.

Clay mineral, such as montmorillonite, has the following ideal chemical formula:

$$
\mathrm{M}_{\mathrm{x}}\left[\mathrm{Al}_{2-\mathrm{x}} \mathrm{Mg}_{\mathrm{x}}\right] \mathrm{Si}_{4} \mathrm{O}_{10}(\mathrm{OH})_{2}
$$

where: $\left[\mathrm{Al}_{2-\mathrm{x}} \mathrm{Mg}_{\mathrm{x}}\right]=$ octahedral cations;

$\mathrm{Si}_{4}=$ tetrahedron cations;

$(\mathrm{OH})_{2}=$ anions;

$\mathrm{M}=$ interlamellar cations, such as: $\mathrm{Ca}^{2+}, \mathrm{Mg}^{2+}, \mathrm{Na}^{+}, \mathrm{NH}_{4}^{+} \ldots$;

$\mathrm{X}=$ varies according to the permanent charge present in the tetrahedron and octahedron leaf.

Between the lamellae, hydration water and compensation cations may coexist, which are capable of ion exchange. Clays also have the property of expanding, or swelling, by introducing more water or other solvents into the interlayer region.

Table 2 shows some examples such as classification of clays into groups and subgroups, according to their species, location and chemical formula studied as an international standard.

\subsection{Soils Derived from Basalt}

Basalt is a rock rich in basic cations, such as, $\mathrm{Na}^{+}, \mathrm{K}^{+}, \mathrm{Ca}^{2+}, \mathrm{Mg}^{2+}$, micronutrients and has a high content of primary minerals that are easily weathered, such as olivines and pyroxenes. Therefore, in this sense, it deduces that all soils derived from basalt would tend to be of the eutrophic type, with high natural fertility and base saturation. In reality, this trend is often not confirmed, due to the

Table 2. Location and constitution of mineral phyllosilicates from the clay fraction studied as standard, where Uni $=$ unioctahedron and $\mathrm{Di}=$ dioctahedron.

\begin{tabular}{|c|c|c|c|}
\hline Type & Group & Subgroup & Species/Location/Formula \\
\hline $2: 1$ & Clay & Smectite (Di) & $\begin{array}{c}\text { Montmorillonite }(\mathrm{SWy}-2)\left(^{*}\right) \\
\text { Crook County, WY } \\
\mathrm{Na}_{0.3} \mathrm{Al}_{1.7} \mathrm{Mg}_{0.3} \mathrm{Si}_{4} \mathrm{O}_{10}(\mathrm{OH})_{2}\end{array}$ \\
\hline $2: 1$ & Clay & Smectite (Di) & $\begin{array}{l}\left.\text { Montmorillonite }(\mathrm{SAz}-1){ }^{*}\right) \\
\text { Cheto Mine, Apache Country, } \mathrm{AZ} \\
\mathrm{Ca}_{0.3} \mathrm{Al}_{1.6} \mathrm{Mg}_{0.3} \mathrm{Si}_{4} \mathrm{O}_{10}(\mathrm{OH})_{2}\end{array}$ \\
\hline $2: 1$ & Clay & Smectite (Di) & $\begin{array}{c}\text { Montmorillonite STx }-1\left({ }^{* * *}\right) \\
\text { county of Gonzales, Texas/USA } \\
(\mathrm{Na}, \mathrm{Ca})_{0.33}(\mathrm{Al}, \mathrm{Mg})_{2} \mathrm{Si}_{4} \mathrm{O}_{10}(\mathrm{OH})_{2} \cdot \mathrm{nH}_{2} \mathrm{O}\end{array}$ \\
\hline $1: 1$ & Clay & Kaolinite (Uni) & $\begin{array}{c}\text { Kaolinite Kga-1 }\left(^{* *}\right) \\
\text { County of Washington, State of Georgia, USA } \\
\mathrm{Al}_{2} \mathrm{Si}_{2} \mathrm{O}_{5}(\mathrm{OH})_{4}\end{array}$ \\
\hline
\end{tabular}

Source: $\left(^{*}\right)$ Chipera, et al. (1993) [6], $\left(^{* *}\right)$ Gupta, et al. (2005) [7], $\left(^{* * *}\right.$ Chipera and Bish (2001) [8]. 
agents and degree of weathering acting on these soils. Therefore, only the soil matrix rock does not guarantee the chemical potential that a soil can present.

\subsection{Organic Matter in Soil}

The organic matter present in the soil is represented by decaying plant residues, the most stable fraction being called humus, in addition to microbial biomass and crop residues (Bayer, 2008) [9].

The humic fraction can contribute approximately $15 \%$ of the total organic carbon in soils, being represented by carbohydrates, lignin, lipids, organic acids and proteins. Tropical climate soils are commonly found between 1.0\%-5.0\% organic carbon, depending on environmental conditions, soil texture and vegetation type. Its dynamics are influenced by mechanisms that control carbon cycling, being the main contributor to the chemical and physical aspects of the soil, as described by Albers et al. (2001) [10].

As described by Novotny (2002) [11], the model that was proposed by Schulten and Schnitzer (1995) [12], organic matter is a three-dimensional structure and, based on mathematical studies, the model presented empty spaces of different sizes, where organic compounds, hydrophilic or hydrophobic, can bind the structure. The letters A, B and C represent the spaces where the molecule can interact with other compounds and the colors represent the atoms: i) blue (carbon), ii) white (hydrogen), iii) red (oxygen) and iv) black (nitrogen), as shown in Figure 1.

Organic matter, due to its physicochemical characteristics, can develop different important processes in the environment, such as control of soil temperature, water retention capacity, pedogenesis processes and ion absorption by plants, favoring productivity (Novotny, 2002) [11].

\subsection{Spectroscopy in the Infrared Region}

The infrared (IR) spectrum consists of the graphic representation of the correlation between the absorbance or transmittance intensity and the energy of the IR

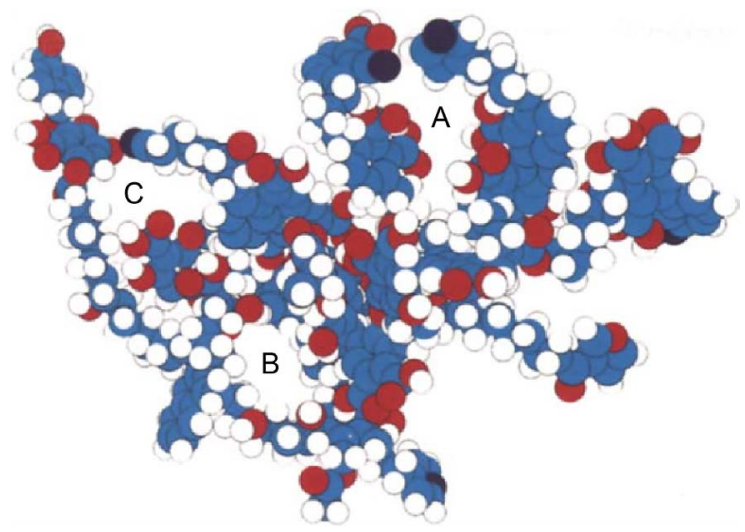

Figure 1. Model for humic acid proposed by Schulten and Schnitzer (1995) [12], where the colors represent blue (carbon), white (hydrogen), red (oxygen) and black (nitrogen). 
radiation, expressed in number of waves. The application of this technique in the analysis of humic substances is widely used in its characterization and can be applied to solid, liquid and gaseous samples. The difficulty regarding the broader application of the (IR) technique in humic substances lies in the complexity of the spectrum assessment and the low degree of purity of the samples (Canellas et al., 2005) [13].

The division of the region of the electromagnetic spectrum corresponding to infrared into three sub-regions, near infrared $\left(14,290-4,000 \mathrm{~cm}^{-1}\right)$, mid infrared $\left(4,000-400 \mathrm{~cm}^{-1}\right)$ and far infrared $\left(700-200 \mathrm{~cm}^{-1}\right)$, situated between the visible and microwave regions. The most useful portion is located between 4,000 and $625 \mathrm{~cm}^{-1}$ (Silverstein, 1979) [14].

If a molecule absorbs energy from electromagnetic radiation, it can have various types of excitation. Excitation can cause several types of effects, such as: i) electronic excitation, ii) rotational excitation, iii) nuclear spin change, iv) bond deformation, etc. If the available energy approaches the ionization potential, an electron can escape "electronic sphere" and ionization occurs. As each type of excitation requires a specific amount of energy, the absorption will occur in different regions of the electromagnetic spectrum, making the determination of the position of the functional group its identification.

Within the (IR) spectroscopy, they may present problems associated with the method of evaluating the samples, for example, the making of the pellet with $\mathrm{KBr}$, as the interference of the water molecule associated with the pellet must be given full attention, that is, both sample like $\mathrm{KBr}$ salt must be dry. These difficulties can be reduced when working with the Total Reflectance (ATR) attenuator accessory, which can be carried out with dry mass samples and represents a faster and more practical IR-ATR technique due to simplicity.

Table 3 shows absorption region in wavenumber $\left(\mathrm{cm}^{-1}\right)$ of some functional groups and chemical bonds observed by Flaig et al. (1975) [15], in the evaluation of humic substances.

The infrared spectral vibrations of silicates can be roughly separated, due to $\mathrm{OH}$ groups, tetrahedra groups, octahedra cations, and interlayer cations (Farmer, 1974) [16].

The absorption of IR radiation is also strongly influenced by the degree of crystallinity of the mineral (Lazarev, 1974) [17], and the size and shape of mineral particles (Serna et al., 1982) [18].

Therefore, the IR spectrum of a clay mineral is sensitive to chemical composition, isomorphic substitution and crystallinity, and not only provides fundamental information for mineral identification, but also on surface properties and reactions of minerals with chemical substances in the environment. Although there are techniques for semiquantitative evaluation of functional groups of minerals by infrared spectroscopy (Baes \& Bloom, 1989) [19], the spectra, in general, provide essentially qualitative information. The information provided by the comparative analysis between standard spectra is more reliable than the 
Table 3. Vibration bands related to the connections of the groups responsible for absorption in the IV region of humic substances (Flaig et al., 1975) [15].

\begin{tabular}{cc}
$\begin{array}{c}\text { Wave number } \\
\left(\mathrm{cm}^{-1}\right)^{*}\end{array}$ & Bonds responsible for absorption \\
\hline 3413 & OH with hydrogen bonds \\
3226 & OH with intermolecular bonds \\
3077 & $\mathrm{C}-\mathrm{H}$ of aromatics (related to organic matter) \\
2941 & $\mathrm{CH}$, aliphatic $\mathrm{CH}_{2}$ and $\mathrm{CH}_{3}$ lateral to aromatic nuclei \\
2849 & carboxylic acid $-\mathrm{OH}$ \\
2500 & Amine or amino acid derivatives \\
1709 & $\mathrm{C}=\mathrm{O}$ of various groups of carboxylic acids, cyclic and acyclic aldehydes and \\
& ketones \\
1615 & $\mathrm{C}$ of double bonds in aliphatic and aromatic compounds. \\
1550 & $\mathrm{C}=\mathrm{N}$ of heterocyclics \\
1449 & $\mathrm{C}-\mathrm{H}$ of methyl and methylene groups \\
1389 & Salts of the carboxylic acid groups \\
1300 & $\mathrm{C}=\mathrm{N}, \mathrm{NH}_{\text {(amide }}$ \\
1267 & $\mathrm{C}-\mathrm{O}-\mathrm{CH}_{3}$ aromatic \\
1216 & $\mathrm{C}-\mathrm{The}$ ester, ether and phenol \\
1031 & Silicates \\
1035 & O-CH $\mathrm{H}_{3}$ \\
\hline
\end{tabular}

$\left.{ }^{*}\right)$ wave number is the reciprocal of the wavelength, when the latter is expressed in centimeters.

analysis of a spectrum alone. The presence of impurities, for example, can be observed by analyzing the spectrum before and after the removal process (Piccolo, 1988) [20].

Table 4 shows the wave number $\left(\mathrm{cm}^{-1}\right)$ of some connections and groupings, evaluated by Ahlrichs (1968) [21], for clay minerals.

With the development of new evaluation techniques, such as infrared with the Fourier transform with a total reflectance attenuator (FTIR-ATR), a higher speed in the reading of the spectra was obtained, allowing to obtain a sum of many spectra, improving signal definition and analysis accuracy (Benites et al., 1999) [22].

Therefore, the objective of this work was to evaluate the nature of minerals in the clay fraction of four soils of a basalt-derived toposequence, observing the separation with dithionite-citrate-sodium bicarbonate and in the absence of organic matter, using spectroscopy as a tool in the Fourier transform infrared region (FTIR).

\section{Methodology}

The study was carried out using samples collected from Horizons A ( $0-0.2 \mathrm{~m}, \mathrm{~B}$ and $C$ from the profiles of four units of soil classes of a toposequence derived from basalt, located in the municipality of Maringá, State of Paraná.

The soil samples from the toposequence are classified as: i) LATOSOIL Dystroferric Red (LVdf), ii) NITOSOIL Eutroferric Red (NVef), iii) CHERNOSOIL Ferric Argiluvic (MTf) and iv) VERTISOIL Ortic Hydromorphic (VGo), as described by EMBRAPA (1999) [23]. 
Table 4. Hydroxyl vibration bands for water and structural in clays.

\begin{tabular}{cc}
\hline Wave number $\left(\mathrm{cm}^{-1}\right)$ & Vibration \\
\hline 3630 & structural stretching of hydroxyl groups $(\mathrm{OH})$ \\
3430 & stretch $(\mathrm{OH})$ of water \\
1630 & deformation $(\mathrm{OH})$ of water \\
1115 & stretch (longitudinal) $\mathrm{SiO}$ \\
1045 & SiOSi stretch \\
920 & AlAlOH deformation \\
885 & AlFeOH deformation \\
850 & MgAlOH deformation \\
800 & SiO stretching of quartz and silica \\
778 & quartz SiO stretch \\
620 & AlO and SiO coupling, out of plane \\
524 & AlOSi deformation \\
466 & SiOSi deformation \\
\hline
\end{tabular}

Source: (Ahlrichs, 1968) [21].

The classification of soils in the Brazilian Soil Classification System (EMBRAPA, 1999) [23] and in the American Classification System (USDA, 1992) [24] are presented in Table 5.

\subsection{Experimental Treatments}

\subsubsection{Determination of Total Organic Carbon}

The organic carbon content was obtained through wet oxidation of soil matter (Walley-Black method) with potassium dichromate in a sulfuric medium.

$0.5 \mathrm{~g}$ of sample was added to a $250 \mathrm{ml}$ Erlenmeyer flask. $10 \mathrm{~mL}$ of $0.5 \mathrm{~mol} / \mathrm{L}$ $\mathrm{K}_{2} \mathrm{Cr}_{2} \mathrm{O}_{7}$ solution were added, followed by $20 \mathrm{~mL}$ of $98 \% \mathrm{H}_{2} \mathrm{SO}_{4}$, manually shaken for one minute and left to rest for 30 minutes. After this period, $100 \mathrm{~mL}$ of deionized water, $10 \mathrm{~mL}$ of $85 \% \mathrm{H}_{3} \mathrm{PO}_{4}$, and six drops of $1 \%$ diphenylamine were added. Then, it was titrated with a $0.5 \mathrm{~mol} \cdot \mathrm{L}^{-1}$ ammoniacal ferrous sulfate solution until the dark blue color changed to green. From the spent volume, the "organic matter" content of the soil sample was calculated, as described by (EMBRAPA, 1997) [25].

\subsubsection{Removal of Organic Matter}

The oxidation of organic matter present in the sample of each soil was performed using sodium hypochlorite $(\mathrm{NaOCl})$, as described by (Lavkulich et al., 1970) [26], seeking to avoid possible changes in minerals or the formation of calcium oxalate by the treatment with hydrogen peroxide, as reported by (Dowdy, 1994) [27].

Initially, the clay fraction samples from the four soils (LVdf, NVef, MTf and VGo) were subjected to treatment with $6 \%$ sodium hypochlorite $\mathrm{pH} 9.5$ at a ratio of 1:3 and remained at rest for 72 hours, with exchange of supernatant every 24 hours and kept in an oven at $65^{\circ} \mathrm{C}$. Afterwards, the samples were washed with deionized distilled water until electrical conductivity was close to that of water (Lavkulich et al., 1970) [26]. Afterwards, they were dried in an oven at $65^{\circ} \mathrm{C}$ for 
Table 5. Relevant information of the four soils of the toposequence derived from basalt, located in the municipality of Maringá.

\begin{tabular}{cccc}
\hline $\begin{array}{c}\text { Brazilian system of soil classification } \\
\text { (EMBRAPA, 1999) [23] }\end{array}$ & USDA (1992) [24] & Altitude (m) & Distance (m) \\
\hline LATOSOIL Dystroferric Red-LVdf & Haplortox & 550 & 0 \\
NITOSOIL Eutroferric Red-NVef & Paleudalf & 535 & 700 \\
CHERNOSOIL Ferric Argiluvic-MTf & Argiudoll & 524 & 1350 \\
VERTISOIL Ortic Hydromorphic-VGo & Endoaquerts & 500 & 2000 \\
\hline
\end{tabular}

72 hours. Soil samples with organic content were defined with (CMO) and without organic content (SMO). Afterwards, the samples were sieved in a 0.84 $\mathrm{mm}$ mesh and saved for FTIR spectroscopic analysis.

\subsubsection{Dissolution-DCB}

The soil samples referring to the clay fraction were treated with dithionite-citrate-sodium bicarbonate (DCB), according to Mehra and Jackson (1960) [28].

In $100 \mathrm{~mL}$ test tubes, $2.0 \mathrm{~g}$ of soil sample referring to the clay fraction, $40 \mathrm{~mL}$ of $0.3 \mathrm{~mol} \cdot \mathrm{L}^{-1}$ sodium citrate, $5 \mathrm{~mL}$ of $1.0 \mathrm{~mol} \cdot \mathrm{L}^{-1}$ sodium bicarbonate and $1.0 \mathrm{~g}$ were added of powdered sodium dithionite. The mixture was kept in a thermostat bath for 30 minutes at $65^{\circ} \mathrm{C}$. After this period the sample received another 1.0 $\mathrm{g}$ portion of sodium dithionite, under periodic agitation using a vortex, at a temperature of $80^{\circ} \mathrm{C}$, for complete dissolution of the iron oxides and hydroxide observed by the gray coloration of the residual solid material. After dissolution, the solid material and extract were separated by centrifugation. The material was washed with $100 \mathrm{~mL}$ of water, flocculated and lyophilized for further analysis.

\subsubsection{Spectroscopy Analysis in the Infrared Region}

For the FTIR analyses, $1.0 \mathrm{mg}$ of the soil sample of the clay fraction, as already defined, (DCB), (CMO) and (SMO) and $100 \mathrm{mg}$ of dry $\mathrm{KBr}$ were used, where the samples were macerated in an agate mortar, to preparation of the tablets. The spectra were obtained with a resolution of $4 \mathrm{~cm}^{-1}$, in the range of 4,000 - 400 $\mathrm{cm}^{-1}$ and a speed of $21 \mathrm{scan} / \mathrm{min}$ in a Fourier transform infrared (FTIR) spectrophotometer, Bomem MB 105 model.

To plot the FTIR spectra outside the equipment, the Microcal Origin program was used with data imported from the analysis, where the vibration bands of the connections and functional groups were evaluated, as described by Benites, et al. (1999) [22] and Ahlrichs (1968) [21].

\section{Results and Discussion}

The studied soils show common chemical characteristics of soils derived from the basic volcanic rocks of the Trapp Spill (EMBRAPA, 1984) [29]. The soils are clayey and have a low content of sand and silt. Pedogenetic processes determine a behavior gradient between more weathered soils (LVdf and NVef) and less de- 
veloped soils (MTf and VGo), as described by Peternele et al. (2014) [30].

It can be seen in Table 6 that less developed soils have higher contents of 2:1 silicate minerals, on the contrary, LVdf and NVef soils have higher contents of iron and aluminum oxyhydroxide that are concentrated in the system, as the advancement of the activity of the weathering process.

It can also be observed that the organic carbon content of the soil sample (LVdf) has the highest content. Consequently, this high content of organic matter can influence the adsorption process of metallic ions present in the system, making it difficult to extract the element, as observed by Petruzzelli et al. (1985) [31].

Clay fraction minerals, such as Gibbsite [Gb], Kaolinite [Kao], were determined by thermogravimetric analysis (TGA), as described by Peternele et al. (2014) [30]. The amount of expandable 2:1 clay minerals (smectite and/or vermiculite) $[\mathrm{EM}]$, of the clay fraction was determined by difference using the expression:

$$
\% \mathrm{EM}=100 \%-[\% \mathrm{Fe}(\mathrm{DCB})+\% \mathrm{Gib}+\% \mathrm{Kao}]
$$

Expression as described by Costa et al. (1999) [32], follows the fractionation of mineral species from the clay fraction, as observed by Sarwenay (2008) [33].

In toposequence soils, kaolinite contents are related to gibbsite contents, which tend to decrease, as the soils present characteristics of poorly developed soils, that is, less weathered. However, there is an increase in the contents of expandable 2:1 clay minerals, such as smectites.

\subsection{FTIR Analysis}

The Fourier transform infrared (FTIR) spectra of soil samples from the clay fraction treated with DCB, referring to horizons A, B and C, are shown in Figure 2. The FTIR spectra of soil samples developed in toposequence in both the treatments, with organic matter (CMO) and without organic matter (SMO), are shown in Figure 3.

The attributions of the bands based on the cited literature were observed to identify the characteristic absorption of different functional groups in the infrared region. A system used in the interpretation is the division of the observed

Table 6. Contents of gibbsite, kaolinite, minerals type 2:1, organic C and iron (DCB), for the different classes of soils in the presence of organic matter.

\begin{tabular}{cccccc}
\hline Soil & Gb & Kao & EM & $\begin{array}{c}\text { C organic } \\
\left(\mathrm{g} \cdot \mathrm{dm}^{-3}\right)\end{array}$ & $\begin{array}{c}\text { Iron (DCB) } \\
\%\end{array}$ \\
\cline { 2 - 4 } & & $\%$ & & 16.69 & 19.50 \\
LVdf & 4.23 & 70.97 & 3.53 & 12.78 & 20.12 \\
NVef & 2.09 & 67.45 & 8.29 & 14.00 & 16.37 \\
MTf & 1.83 & 63.65 & 16.33 & 14.08 & 8.01 \\
VGo & 0.00 & 55.13 & 36.11 & 13 \\
\hline
\end{tabular}

$\mathrm{Gb}=$ Gibbite, $\mathrm{Kao}=$ Kaolinite and $\mathrm{EM}=2: 1$ expansive minerals (smectite and/or vermiculite). Source: Peterneleet al. (2014) [30]. 


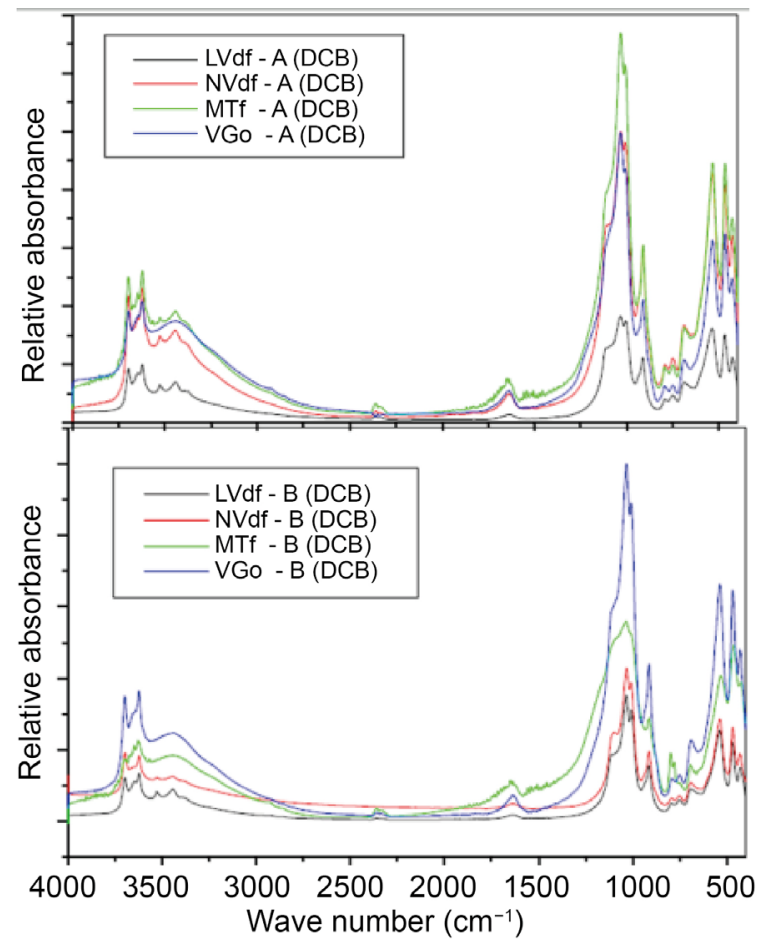

Figure 2. FTIR spectra of clay fraction samples above horizon $[\mathrm{A}]$ and below horizons [B and C], after treatment with DCB for soils: LATOSOIL Dystroferric Red (LVdf), NITOSOIL Eutroferric Red (NVef), CHERNOSOIL Ferric Argiluvic (MTf) and VERTISOIL Orthic hydromorphic (VGo).

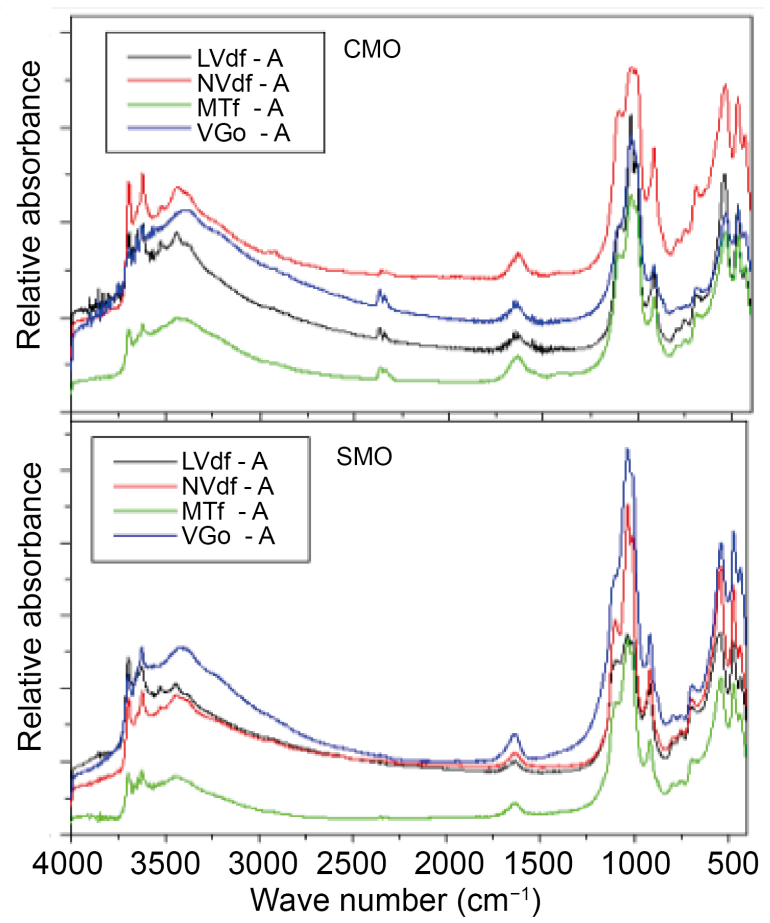

Figure 3. FTIR spectra of samples of the clay fraction from the horizon [A] of samples in the presence of organic matter [CMO] and after removal of organic matter [SMO] for the soils: LATOSOIL Dystroferric Red (LVdf), NITOSOIL Red Eutroferric (NVef), CHERNOSOIL Ferric Argiluvic (MTf) and VERTISOIL Ortic Hydromorphic (VGo). 
interval $\left(4000-400 \mathrm{~cm}^{-1}\right)$ into specific regions:

\subsubsection{Region $\mathrm{I}=4000-2000 \mathrm{~cm}^{-1}$}

In this region, absorptions corresponding to the stretching of $-\mathrm{OH}$ and $\mathrm{C}-\mathrm{H}$ bonds are observed.

Absorptions relative to the $-\mathrm{OH}$ stretch of organic content are always presented as a broad and intense band, due to the - $\mathrm{OH}$ groups that form intra and intermolecular hydrogen bonds, with absorptions in the ranges of $3600-3440$ and $3550-3200 \mathrm{~cm}^{-1}$, respectively.

Absorptions relative to the - $\mathrm{OH}$ stretch of the inner surface of kaolinite appear at 3694,3669, 3653 and $3620 \mathrm{~cm}^{-1}$, while for smectites the structural $\mathrm{OH}$ stretch occurs at 3632 and $3627 \mathrm{~cm}^{-1}$.

It can be observed, in general, that the band close to $3630 \mathrm{~cm}^{-1}$ is due to structural $\mathrm{OH}$ groups. Another stretch that follows arises from the vibration also of the $\mathrm{OH}$ group of the water, a wide band at $3430 \mathrm{~cm}^{-1}$ that can be attributed to the $\mathrm{H}-\mathrm{O}-\mathrm{H}$ that stretches in the system referring to the water released when heating the sample. This band reflects the water adsorbed onto the structure or between layers of the clay mineral.

The 2950 and $2850 \mathrm{~cm}^{-1}$ vibration bands are attributed to stretching of C-H bonds of aliphatic and -OH groups of carboxylic acids, respectively. This observation is evidenced in samples with the presence of organic matter.

The characteristic band observed at $2400 \mathrm{~cm}^{-1}$ is related to $\mathrm{CO}_{2}$.

\subsubsection{Region II = $2000-1000 \mathrm{~cm}^{-1}$}

The absorption band close to $1630 \mathrm{~cm}^{-1}$ is due to the deformation of the $\mathrm{H}-\mathrm{O}-\mathrm{H}$ bonds related to the water molecules of crystallization and the stretching of $-\mathrm{C}=\mathrm{C}$ - of aliphatic and aromatic groups in $1615 \mathrm{~cm}^{-1}$.

There is a relevant observation in the coordination of charges of carboxylic origin with metals by covalent bonds which cause the displacement of the resonant frequency of the axial deformation of the $\mathrm{C}=\mathrm{O}$ bond of the carboxylic group in $1712 \mathrm{~cm}^{-1}$ for a range of $1630-1615 \mathrm{~cm}^{-1}$, according to the metallic species involved and the form of coordination, as described by Vinkler, et al. (1976) [34].

The band that appears in a strong way, close to $1115 \mathrm{~cm}^{-1}$, is due to the longitudinal vibration of the $\mathrm{Si}-\mathrm{O}$ bonds and the absorption related to the Si-O perpendicular stretch occurs at approximately $1100 \mathrm{~cm}^{-1}$. The band close to 1045 $\mathrm{cm}^{-1}$, which appears strongly, is related to the Si-O-Si system bonds present in phyllosilicate minerals, more precisely related to smectites, resulting from stretching in the Si-O plane. As for kaolinites, this stretching in the Si-O system plane occurs at 1033 and $1011 \mathrm{~cm}^{-1}$.

\subsubsection{Region III $=1000-400 \mathrm{~cm}^{-1}$}

The bands observed at 920,885 and $842 \mathrm{~cm}^{-1}$ are due to deformations of the bonds between AlAl-OH, AlFe- $\mathrm{OH}$ and $\mathrm{Mg}-\mathrm{Al}-\mathrm{OH}$, respectively.

The bands close to 885 and $842 \mathrm{~cm}^{-1}$ are of low intensity. Another weak band 
near $800 \mathrm{~cm}^{-1}$ is attributed to quartz and silica vibrations, as the weak band near $778 \mathrm{~cm}^{-1}$ is attributed to quartz vibrations. The absorption band at $620 \mathrm{~cm}^{-1}$ is due to $\mathrm{Al}-\mathrm{O}$ and Si-O coupling, out of plane and the bands 524 and $466 \mathrm{~cm}^{-1}$ are due to deformation of the Al-O-Si and Si-O-Si bonds, respectively.

In Figure 2 and Figure 3, the FTIR spectra of soil samples from the toposequence derived from basalt, where the interval between the 450 and $550 \mathrm{~cm}^{-1}$ absorption bands can be observed, which can be attributed to angular deformation or combinations of Si-OM bonds, where $(\mathrm{M}=\mathrm{Al}, \mathrm{Fe}$ and $\mathrm{Mg})$. In the present study, these vibrations are observed at 470 and $528 \mathrm{~cm}^{-1}$.

It is also possible to observe the presence of kaolinite from the 3698,3624 and $913 \mathrm{~cm}^{-1}$ bands, which are attributed to the $\mathrm{OH}$ groups connected to the outer octahedron layer, with well-defined peaks, as also observed by Madejová and Komadel (2001) [35].

Although there is no band at $1720 \mathrm{~cm}^{-1}$ in the treatment of samples (CMO), referring to the indication of carbonyl stretch of the carboxylic group, it does not mean that there is no organic matter in the respective fractions, rather indicating the low content of organic content present in the samples, which can be confirmed by the presence of aliphatic $\mathrm{CH}$ and $\mathrm{CH}_{2}$ bonds in $2930 \mathrm{~cm}^{-1}$ and by the broadening of the band referring to structural $\mathrm{OH}$, in addition to the stretching of the $-\mathrm{C}=\mathrm{C}$ - bond, when compared with the same samples without the organic material (SMO) which can be seen in Figure 3.

The band observed at $2400 \mathrm{~cm}^{-1}$ refers to $\mathrm{CO}_{2}$ released during the heating of the sample from the IR laser, being of greater intensity in the samples (CMO), indicating its origin in the organic matter present in the soil. In the samples (SMO), a slight band signal is observed, which confirms the efficiency of the organic matter removal process, as described by Lavkulich et al. (1970) [26].

The change in the absorption band from 1725 to $1625 \mathrm{~cm}^{-1}$, characteristic of a carboxyl group, is due to the adsorption of organic matter on goethite and gibbsite, as described by Kaiser et al. (1997) [36]. These binding forms are quite common in tropical soils, being considered the main binding mechanisms in the formation of organomineral complexes (Varadachari et al., 1997) [37].

The FTIR spectra of Figure 2 and Figure 3 obtained for the clay fraction (DCB) and fraction (CMO) phyllosilicates (SMO), respectively, demonstrate characteristic peaks in common regions, varying in intensity, but with little variation in absorbance frequencies, indicating that the dissolution and separation processes are suitable for evaluating the absorption bands.

There is a large absorption range around a wave number of $3400 \mathrm{~cm}^{-1}$, due to the high concentration of $\mathrm{OH}$ groups from gibbsite, montmorillonite, kaolinite and water. Gibbsite can be observed from the absorption bands at 3528 and 3452 $\mathrm{cm}^{-1}$ and weak bands between 3380 and $3398 \mathrm{~cm}^{-1}$, as described by Russell and Fraser (1994) [38].

Figure 4 shows the FTIR spectra of phyllosilicates, such as montmorillonite-Na (SWy-2), montmorillonite-Ca (SAz-1) and kaolinite (KGa-1b), which 


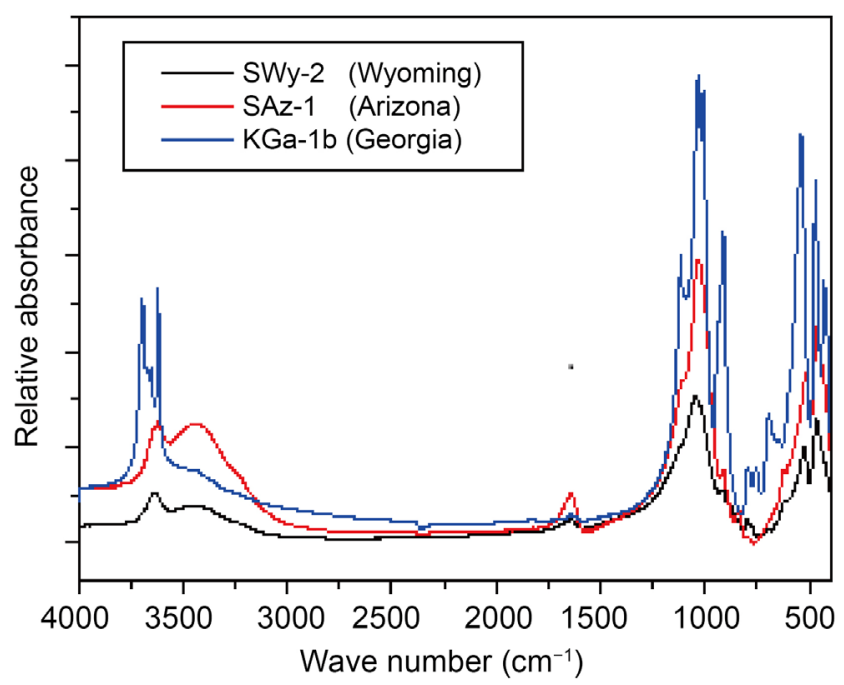

Figure 4. FTIR spectra of montmorillonite- $\mathrm{Na}$ (SWy-2) of Wyoming, montmorillonite-Ca (SAz-1) of Arizona and kaolinite (KGa-1b) of Georgia minerals.

are classified as an international standard due to their physical properties-chemical and composition.

It was also used to analyze the FTIR spectra, the area ratio calculation technique (in $\mathrm{mm}^{2}$ ) with the aid of the Softwear tool Microcal Origin, the absorption bands and the kaolinite peak (KGa-1b) in $1042 \mathrm{~cm}$ as a standard. -1 as a reference, due to its larger area, compared to the montmorillonites SWy-2 and SAz-1.

Area 1 (A1) was called the peak of the interval $\left[3700-3550 \mathrm{~cm}^{-1}\right]$ referring to the structural stretching of the - $\mathrm{OH}$ groups of the inner surface of kaolinite, area 2 (A2) was the peak of the interval [3500 $\left.-3250 \mathrm{~cm}^{-1}\right]$ referring to the stretching of internal structural -OH groups and water, and area 3 (A3) the peak of the interval $\left[1300-840 \mathrm{~cm}^{-1}\right]$ referring to Si-O stretching in the plane and Al-M-type deformations $\mathrm{OH}$ (where $\mathrm{M}$ can be $\mathrm{Al}, \mathrm{Fe}$ and $\mathrm{Mg}$ ) and area 4 (A4) to the standard peak of the silicates, in the evaluation of kaolinite (KGa-1b) with 66.84 $\mathrm{mm}^{2}$ and absorption in $\left(1042 \mathrm{~cm}^{-1}\right)$, as shown in Figure 4. The results of the area list are shown in Table 7.

The phyllosilicates of the clay group present an intense absorption band at $1042 \mathrm{~cm}^{-1}$ that characterize them. For montmorillonite, this band should be evident at $1100 \mathrm{~cm}^{-1}$. As also observed by Besson et al. (1987) [39], this shift to low frequencies is due to the $\mathrm{Al}^{3+}$ ions that took the place of the $\mathrm{Si}$ atoms in the tetrahedron structure, a process called isomorphic substitution.

In Table 7, it is observed that the band ratios are higher for the LVdf and NVef classes in the treatment (DCB) for the A horizon, with similar values, indicating the presence of a high amount of kaolinite, which corroborates the results obtained by TGA and XRD, which is associated with the high degree of weathering of these classes, as also observed by Peternele et al. (2014) [30].

For the LVdf class in the treatment (DCB) horizon $\mathrm{B}$, that is, the horizon frequently used in the assessment of the mineralogy of the soil class, there was also 
Table 7. Ratio of FTIR spectrum absorption peak areas of clay fraction samples treated with (DCB) in A/B/C horizons, for soils LATOSOILDystroferric Red (LVdf), NITOSOILEutroferric Red (NVef), CHERNOSOIL Ferric loam (MTf) andVERTISOILOrtic Hydromorphic (VGo).

\begin{tabular}{ccccc}
\hline Ratio (area) & $\begin{array}{c}\text { LVdf } \\
\text { Area - ratio }\end{array}$ & $\begin{array}{c}\text { NVef } \\
\text { Area - ratio }\end{array}$ & $\begin{array}{c}\text { MTf } \\
\text { Area - ratio }\end{array}$ & $\begin{array}{c}\text { VGo } \\
\text { Area - ratio }\end{array}$ \\
\hline A1/A4* & $24.84-0.37$ & $28.28-0.42$ & $18.82-0.28$ & $7.48-0.11$ \\
A2/A4 & $13.02-0.20$ & $14.87-0.22$ & $12.28-0.18$ & $11.90-0.17$ \\
A3/A4 & $81.24-1.21$ & $108.76-1.62$ & $97.29-1.45$ & $58.61-0.87$ \\
A1/A4 & & & & \\
A2/A4 & $33.80-0.50$ & $17.53-0.26$ & $14.70-0.22$ & $20.24-0.30$ \\
A3/A4 & $17.55-0.26$ & $5.91-0.08$ & $15.49-0.23$ & $13.55-0.20$ \\
\hline
\end{tabular}

$\left.{ }^{*}\right)$ A4 - Ratio Kaolinite $(\mathrm{KGa}-1 \mathrm{~b})-$ area $=66.84 \mathrm{~mm}^{2}\left(1042 \mathrm{~cm}^{-1}\right)$.

a greater presence of kaolinite, indicating the class as the most developed in the toposequence, that is, compared to the other three grades, this is the most oxidized grade.

\section{Conclusions}

The evaluation of soil samples by Fourier Transform Infrared Spectroscopy (FTIR) is proved to be a promising tool in the analysis of different classes of soils and minerals of the clay fraction, with the observation of the need for treatment of samples to separate the components for better evaluation, together with the method of area ratio of the characteristic bands of the mineral common to the soil classes of the toposequence.

The mineralogical analyses by FTIR, indicate that the soils have kaolinite as the predominant mineral. The degree of weathering of the toposequence soils was observed by the presence and concentration of some minerals from the clay fraction. The more weathered the soils, the higher the levels of iron and aluminum, in the forms of oxide/iron hydroxide and gibbsite/kaolinite, respectively. Differently, the contents of expandable 2:1 type expandable minerals are lower.

The soils of the toposequence derived from basalt, present differences in the distribution of minerals in the clay fraction, being the most weathered soils, that is, LATOSOIL Dystroferric Red (LVdf) and NITOSOIL Eutroferric Red (NVef) are more evolved.

The organic content presents similar values in the soils of the toposequence with a slight increase for the more evolved (LVdf) class, considering the tropical climate where the content does not exceed $4 \%$ to $5 \%$ of organic matter present in Brazilian soils. 


\section{Acknowledgements}

The authors would like to thank the Departments of Chemistry, Agronomy and the Graduate Program in Agronomy at the State University of Maringá for their support in carrying out the experimental work and laboratory analyses.

\section{Conflicts of Interest}

The authors declare that there are no conflicts of interest regarding the publication of this article.

\section{References}

[1] Manahan, S.E. (2001) Fundamentals of Environmental Chemistry. 2nd Edition, CRC Press LLC, Boca Raton.

[2] Sposito, G. (1985) The Chemistry of Soil. Oxford University Press, New York, 314.

[3] Camargo, O.A., Jacomine, P.K.T., Carvalho, A.P. and Olmos, I.L. (1986) The Brazilian Classification of Latosols. International Soil Classification Workshop: Classification, Characterization and Utilization of Oxisols, Vol. 8. Rio de Janeiro, 190-199.

[4] Santos, P.S. (1989) Clay Science and Technology. 2nd Edition, Edgard Blücher, São Paulo.

[5] Santos, P.S. (1975) Clay Technology. Vol. 1, Editor Edgard Blucher/Universidade de São Paulo, São Paulo, 190.

[6] Chipera, S.J. and Bish, D.L. (1993) Effects of Humidity on Clay and Zeolite Quantitative XRD Analysis. Proceedings of the 30 th Annual Clay Minerals Society Meeting, San Diego, 25-30 September 1993, 53.

[7] Gupta, S.S. and Bhattacharyya, K.G. (2005) Interaction of Metal Ions with Clays: I. A Case Study with Pb (II). Applied Clay Science, 30, 199-208. https://doi.org/10.1016/j.clay.2005.03.008

[8] Chipera, S.J. and Bish, D.L. (2001) Baseline Studies of the Clay Minerals Society Source Clays: Powder X-Ray Diffraction Analyses. Clays and Clay Minerals, 49, 398-409. https://doi.org/10.1346/CCMN.2001.0490507

[9] Bayer, C. and Mielziczuk, J. (2008) Fundamentals of Soil Organic Matter. In: Santos, G.A., Silva, L.S., Canellas, L.P. and Camargo, F.A.O., Eds., Tropical and Subtropical Ecosystems, 2nd Edition, Porto Alegre-RS, Metropole, 7-18.

[10] Albers, A.P.F., Melchiades, F.G., Machado, R., Baldo, J.B. and Bosch, A.O. (2001) A Simple Method of Characterizing Clay Minerals by X-Ray Diffraction. Annals of the 45th Brazilian Congress of Ceramics, Florianópolis, 30 May-2 June 2001, 1-11.

[11] Novotny, E.H. and Martin-Neto, L. (2002) Effects from Humidity and Metal Ions on the Free Radical Analysis of Peat Humus. Geoderma, 106, 305-317. https://doi.org/10.1016/S0016-7061(01)00130-6

[12] Schulten, H.R. and Schnitzer, M. (1995) Three-Dimensional Models for Humic Acids and Soil Organic Matter. Naturwissenschaften, 82, 487-498.

https://doi.org/10.1007/BF01134484

[13] Canellas, L.P. and Santos, G.A. (2005) Humosphere: Preliminary Reatise on the Chemistry of Humic Substances. UENF, Campos dos Goytacazes, Rio de Janeiro, 309.

[14] Silverstein, R.M., Bassler, G.C., Morril, T.C. and Bryce, D.L. (1979) Spectrometric Identification of Organic Compounds. John Wiley \& Sons, Inc., Translation, Ed. 
Guanabara Koogan, New York, 299.

[15] Flaig, W., Beutel, S., Pacher, H. and Oades, J.M. (1975) Chemical Composition and Physical Properties of Humic Substances. In: Giese King, J.E., Ed., Soil Components: Organic Components, Springer-Verlag, New York, 1-211. https://doi.org/10.1007/978-3-642-65915-7 1

[16] Farmer, V.C. (1974) The Layer Silicates. In: Farmer, V.C., Ed., The Infrared Spectra of Minerals, Mineralogical Society, London, 331-363.

[17] Lazarev, A.N. (1974) The Dynamics of Crystal Lattices. In: Farmer, V.C., Ed., The Infrared Spectra of Minerals, Mineralogical Society, London, 69-86.

https://doi.org/10.1180/mono-4.5

[18] Serna, C.J., Rendon, J.L. and Iglesias, J.E. (1982) Infrared Surface Modes in Corundum-Type Microcrystaline Oxides. Spectrochimica Acta Part A: Molecular Spectroscopy, 38, 797-802. https://doi.org/10.1016/0584-8539(82)80070-6

[19] Baes, A.U. and Bloom, P.R. (1989) Difuse Reflectance and Transmition Fourier Transform Infrared (Drift) Spectroscopy of Humic and Fulvic Acids. Soil Science Society of America Journal, 53, 695-700.

https://doi.org/10.2136/sssaj1989.03615995005300030008x

[20] Piccolo, A. (1988) Characterization of Soil Humic Extracts Obtained by Some Organic and inorganic Solvents and Purified by HCl-HF Treatment. Soil Science, 146, 418-426. https://doi.org/10.1097/00010694-198812000-00003

[21] Ahlrichs, J.L. (1968) Hydroxyl Stretching Frequencies of Synthetic Ni-, Al-, and Mg- Hydroxy Interlayers in Expanding Clays. Clays and Clay Minerals, 16, 63-72. https://doi.org/10.1346/CCMN.1968.0160108

[22] Benites, V.M., Mendonça, E.S., Schaefer, C.E.R. and Martin Neto, L. (1999) Humic Acid Characterization of a Podzol and a Red Yellow Latosol by FTIR Spectroscopy and TD Analysis. Revista Brasileira de Ciência do Solo, 23, 543-551. https://doi.org/10.1590/S0100-06831999000300007

[23] EMBRAPA (Empresa Brasileira de Pesquisa Agropecuária) (1999) Brazilian System of Soil Classification. National Soil Research Center, Rio de Janeiro, 412.

[24] United States Department of Agriculture (USDA) (1992) Key to Soil Taxonomy. 5th Edition, Pocahontas Press, Inc., Blacksburg, 541.

[25] EMBRAPA (Empresa Brasileira de Pesquisa Agropecuária) (1997) Soil Analysis Methods Manual. 2nd Edition, National Soil Survey and Conservation Service, Rio de Janeiro, 212.

[26] Lavkulich, L.M. and Wiens, J.H. (1970) Comparison of Organic Matter Destruction by Hidrogen Peroxide and Sodium Hipochlorite and Its Effects on Selected Mineral Constituents. Soil Science Society of America Journal, 34, 755-758 https://doi.org/10.2136/sssaj1970.03615995003400050025x

[27] Dowdy, R.H. (1994) Preconcentration Techiques in Soil Mineralogical Analyses. In: Amonette, J.E. and Zelazny, L.W., Eds., Quantitative Methods in Soil Mineralogy, Soil Science Society of America, Madison, 236-262.

[28] Mehra, O.P. and Jackson, M.L. (1960) Iron Oxide Removal from Soils and Clay by a Dithionite-Citrate System Buffered with Sodium Bicarbonate. Clays Clay Minerals, 7, 317-327. https://doi.org/10.1346/CCMN.1958.0070122

[29] EMBRAPA (Empresa Brasileira de Pesquisa Agropecuária) (1984) Survey and Recognition of Soils in the State of Paraná. Vol. 1/2, Brazilian Agricultural Research Company, National Soil Survey and Conservation Service, Agronomic Institute of Paraná, Londrina, 791. 
[30] Peternele, W.S. and da Costa, A.C.S. (2014) Mineralogical Horizon (A) Evaluation of a Toposequence of Soils Derived from Basalt by Thermal Analysis. Journal of Minerals and Materials Characterization and Engineering, 2, 374-382. https://doi.org/10.4236/jmmce.2014.25042

[31] Petruzzelli, G., Guidi, G. and Lubrano, L. (1985) Ionic Strength Effect on Heavy Metal Adsorption by Soil. Communications in Soil Science and Plant Analysis, 16, 971-986. https://doi.org/10.1080/00103628509367659

[32] Costa, A.C.S., Bigham, J.M., Rhoton, F.E. and Traina, S.J. (1999) Quantification and Characterization of Maghemite in Soils Derived from Volcanic Rocks in Southerrn Brazil. Clays Clay Miner, 47, 466-473. https://doi.org/10.1346/CCMN.1999.0470408

[33] Sarwenay, A. (2008) Clay Mineral Quantification Using Gravimetric Analysis. Dissertation for the Degree of Master of Science in Civil Engineering, University of Texas, Arlington, 84.

[34] Vinkler, P., Lakatos, B. and Meisel, J. (1976) Infrared Spectroscopic Investigations of Humic Substances and Their Metal Complexes. Geoderma, 15, 231-242. https://doi.org/10.1016/0016-7061(76)90077-X

[35] Madejová, J. \& Komadel, P. (2001) Baseline Studies of the Clay Minerals Society Source Clays: Infrared Methods. Clays and Clay Minerals, 49, 410-432. https://doi.org/10.1346/CCMN.2001.0490508

[36] Kaiser, K., Guggenberger, G., Haumeier, L. and Zech, W. (1997) Dissolved Organic Matter Sorption on Subsoils and Minerals Studied by ${ }^{13} \mathrm{C}-\mathrm{NMR}$ and DRIFT Spectroscopy. European Journal of Soil Science, 48, 301-310. https://doi.org/10.1111/j.1365-2389.1997.tb00550.x

[37] Varadachari, C., Chattopadhyay, T.E. and Ghosh, K. (1997) Complexation of Humic Substances with Oxides of Iron and Aluminum. Soil Science, 162, 28-34. https://doi.org/10.1097/00010694-199701000-00005

[38] Russell, J.D. and Fraser, A.R. (1994) Infrared Methods. In: Wilson, M.J., Ed., Clay Mineralogy: Spectroscopic and Chemical Determinative Methods, Chapman \& Hall, London, 11-67. https://doi.org/10.1007/978-94-011-0727-3 2

[39] Besson, G., Drits, V.A., Daynayak, L.G. and Smoliar, B.B. (1987) Analysis of Cation Distribution in Dioctahedral Micaceous Minerals on the Basis of IR Spectroscopy Data. Clay Minerals, 22, 465-478. https://doi.org/10.1180/claymin.1987.022.4.10 